\title{
Oxygen and the Metabolism of Peptostreptococcus anaerobius VPI4330-1
}

\author{
By ETSURO HOSHINO, FRED FRÖLANDER AND JAN CARLSSON \\ Department of Oral Microbiology, University of Umeå, S-901 87 Umeå, Sweden
}

(Received 10 February 1978)

\begin{abstract}
Peptostreptococcus anaerobius VPI4330-1 is an anaerobic organism which has no superoxide dismutase, catalase or peroxidase. It can be protected from the toxic effects of oxygen by catalase in the culture medium. In order to elucidate its mechanisms of oxygen tolerance, the effect of oxygen on the metabolic activity of the organism was studied.

In salt solution supplemented with glucose or pyruvate the organism had a more rapid metabolic rate under aerobic conditions than under anaerobic conditions. There were also significant differences in metabolic end-products obtained under aerobic and anaerobic conditions. The crude cell-free extract had NADH oxidase activity, which reduced oxygen to water, and NADPH oxidase activity, which reduced oxygen to superoxide radicals and hydrogen peroxide. The former specific activity was much higher than the latter.

The results indicate that the main product of intracellular oxygen reactions was water. Deleterious products such as superoxide radicals and hydrogen peroxide were only formed to a limited extent. NADH oxidase may fulfil an important protective role in this organism.
\end{abstract}

\section{INTRODUCTION}

Anaerobic bacteria vary widely in their sensitivity to oxygen (Loesche, 1969). In some species oxygen may only be bacteriostatic, whereas in others it may cause irreversible cellular damage (Morris, 1976). The prevention of growth by oxygen may be due to inactivation of intracellular key components or to the production of toxic substances, intracellularly (Morris, 1975, 1976) or extracellularly (Frölander \& Carlsson, 1977).

Of strains isolated from clinical infections, peptostreptococci are among those which are very sensitive to oxygen (Tally et al., 1975; Bartlett et al., 1976; Carlsson et al., 1977). When single organisms of Peptostreptococcus anaerobius c1lb-a were exposed to atmospheric oxygen on the surface of brain heart infusion agar (Carlsson et al., 1977) or a suspension of $P$. anaerobius vPI4330-1 was aerated in trypticase soy broth (Frölander \& Carlsson, 1977), more than $90 \%$ of the organisms were killed within $1 \mathrm{~h}$. If catalase was added to these media before exposure to oxygen, all organisms survived for $1 \mathrm{~h}$. The death rate and the protecting effect of catalase were similar in aerobic salt solution and aerobic trypticase soy broth. These results indicate that the effect of oxygen was mediated mainly by hydrogen peroxide produced in the media when exposed to oxygen. There was no evidence of intracellular production of toxic products from oxygen.

The low toxicity of oxygen in $P$. anaerobius VPI4330-1 in the presence of extracellular catalase is surprising since neither catalase nor superoxide dismutase activities have been detected in cell-free extracts of the organism (Frölander \& Carlsson, 1977).

Peptostreptococcus anaerobius VPI4330-1 may be similar to Lactobacillus plantarum ATCC 8014 , which has no catalase, peroxidase or superoxide dismutase and yet is tolerant of oxygen because oxygen does not react with its cellular contents (Gregory \& Fridovich, 
1974). Another possibility is that oxygen reacts with the cellular contents of $P$. anaerobius, but toxic products such as hydrogen peroxide and superoxide radicals are not released in the cell. In order to investigate these possibilities, the effect of oxygen on the metabolic activity of $P$. anaerobius vPI4330-1 was studied, and products of oxygen reduction formed in the presence of cell-free extracts and various substrates were identified.

\section{METHODS}

Organism. Peptostreptococcus anaerobius strain VPI4330-1 (ATCC 27337) was obtained from Virginia Polytechnic Institute and State University, Blacksburg, Virginia, U.S.A.

Chemicals. Tryptose, yeast extract and Bacto agar were from Difco and trypticase soy broth was from BBL. NAD, NADP, NADH, NADPH, FAD, cytochrome $c$ (from horse heart), peroxidase (donor:hydrogen-peroxide oxidoreductase, EC 1.11.1.7, from horse-radish), hexokinase (ATP:D-hexose 6-phosphotransferase, EC 2.7.1.1, from yeast), glucose-6-phosphate dehydrogenase (D-glucose-6-phosphate:NADP+ 1-oxidoreductase, EC 1.1.1.49, from yeast), lactate dehydrogenase (L-lactate: $\mathrm{NAD}^{+}$oxidoreductase, EC 1.1.1.27, from pig heart) and alcohol dehydrogenase (alcohol:NAD ${ }^{+}$oxidoreductase, EC 1.1.1.1) were obtained from Boehringer. Cytochrome $c$ (from horse heart, type III) and catalase (hydrogen-peroxide: hydrogen-peroxide oxidoreductase, EC 1.11.1.6, purified powder from beef liver, C10) were from Sigma. Catalase was purified from superoxide dismutase activity by Sephadex G-200 (Pharmacia) gel filtration in $50 \mathrm{~mm}$-potassium phosphate buffer $(\mathrm{pH} 7.0$ ) containing $0.1 \mathrm{M}-\mathrm{KCl}$. One $\mathrm{mg}$ protein of the purified catalase preparation decomposed $25 \mathrm{mmol}$ hydrogen peroxide $\min ^{-1}$ at $25^{\circ} \mathrm{C}(\mathrm{pH} 7 \cdot 0)$. Superoxide dismutase (SOD) (superoxide:superoxide oxidoreductase, EC 1.15.1.1) was from Truett Laboratories, Dallas, Texas, U.S.A. The superoxide dismutase preparation contained 3000 units $\mathrm{mg}^{-1}$ as defined by McCord \& Fridovich (1969). Horse blood (Statens bakteriologiska laboratorium, Stockholm, Sweden) was haemolysed by freezethawing. Polypropyleneglycol 2025 was from BDH. Radioactive compounds were purchased from Japan Radio Isotope Association, Tokyo, Japan. Chromosorb 101 (80/100 mesh), SP-1200, molecular sieve 5A and Chromosorb W (80/100 mesh) were from Supelco, Bellefonte, Pennsylvania, U.S.A. Isomers of methylvaleric acid were from Aldrich-Europe, Beerse, Belgium.

Culture conditions. The organism was grown in an anaerobic glove box in an atmosphere of $10 \%(\mathrm{v} / \mathrm{v})$ $\mathrm{H}_{2}$ and $5 \%(\mathrm{v} / \mathrm{v}) \mathrm{CO}_{2}$ in nitrogen (Yamada \& Carlsson, 1975). It was stored at $4{ }^{\circ} \mathrm{C}$ on blood agar plates (Holdeman \& Moore, 1975) in the anaerobic box.

The salt solution ( $\mathrm{pH} 7 \cdot 0)$ used for the preparation and dilution of cell suspensions contained $\left(\mathrm{g} \mathrm{l}^{-1}\right)$ : $\mathrm{NaCl}, 4 \cdot 3 ; \mathrm{KCl}, 0.42 ; \mathrm{CaCl}_{2}, 0.24 ; \mathrm{MgSO}_{4}, 0.1 ; \mathrm{Na}_{2} \mathrm{HPO}_{4}, 1 \cdot 0 ; \mathrm{KH}_{2} \mathrm{PO}_{4}, 1.0$; and sodium $\beta$-glycerophosphate, 10 (Möller, 1966).

Formation of fermentation products. A culture of $P$. anaerobius VPI4330-1, grown overnight in 1 litre trypticase soy broth, was harvested by centrifugation $(6000 \mathrm{~g}, 10 \mathrm{~min})$ and then washed twice in $40 \mathrm{ml}$ salt solution. Fermentation products were determined in the supernatant fluid of the broth. Organisms were resuspended to give a turbidity $\left(A_{600}\right)$ of 50 (about $3 \times 10^{10} \mathrm{cells} \mathrm{ml}^{-1}$ ). All these procedures were carried out under strictly anaerobic conditions and all solutions were kept at $4{ }^{\circ} \mathrm{C}$. The cell suspension was divided into $1 \mathrm{ml}$ portions; some were brought out from the anaerobic box in closed screw-capped tubes and the others were kept in the box. The cell suspensions were heated at $37^{\circ} \mathrm{C}$ for $10 \mathrm{~min}$ before initiating the experiment by adding $1 \mathrm{ml}$ cell suspension to $1 \mathrm{ml}$ salt solution $\left(37^{\circ} \mathrm{C}\right)$ containing glucose, pyruvate, leucine or various combinations of these substrates. The anaerobic reaction mixtures were kept in the anaerobic box in $15 \mathrm{ml}$ screw-capped tubes in a block thermostat. The aerobic reaction mixtures were kept in $50 \mathrm{ml}$ round-bottomed flasks and were aerated by vigorous shaking in a thermostated water bath. All aerobic reaction mixtures contained $52 \mu \mathrm{g}$ catalase. At $0,5,10,15,20$ and $60 \mathrm{~min}$, samples of $0.2 \mathrm{ml}$ were transferred from the reaction mixtures to vials containing $0.1 \mathrm{ml}$ of an ice-cold $7.5 \%(\mathrm{w} / \mathrm{w})$ solution of metaphosphoric acid. The precipitated material was centrifuged $(12000 \mathrm{~g}, 15 \mathrm{~min})$ and the supernatant fluid was stored at $4{ }^{\circ} \mathrm{C}$ until analysed for fermentation products.

Assay of fermentation products. Glucose was determined with hexokinase and glucose-6-phosphate dehydrogenase (Slein, 1965), pyruvate with lactate dehydrogenase and NADH (Bücher et al., 1965), L-lactate with lactate dehydrogenase and NAD (Hohorst, 1965), D-lactatewith D-lactate dehydrogenase and NAD (Gawehn \& Rergmeyer, 1970), and ethanol with alcohol dehydrogenase and NAD (Bonnichsen, 1965).

Volatile fatty acids $\left(C_{2}\right.$ to $\left.C_{6}\right)$, acetoin, diacetyl, alcohols $\left(C_{2}\right.$ to $\left.C_{5}\right)$, lactate and succinate were assayed by gas chromatography on a Chromosorb 101 column at $200^{\circ} \mathrm{C}$ (Carlsson, 1972) using flame ionization detectors. The samples were treated as described by Yamada \& Carlsson (1975). Formate was determined with a thermal conductivity detector after separation on Chromosorb 101 at $165^{\circ} \mathrm{C}$. For determination of acetate and ethanol, the temperature was decreased to $150^{\circ} \mathrm{C}$. For methylvaleric acid and $\alpha$-ketoisocaproic 
acid, a column of $10 \% \mathrm{SP}-1200 / 1 \% \mathrm{H}_{2} \mathrm{PO}_{4}$ on Chromosorb W (Ottenstein \& Bartley, 1971) was used at $125^{\circ} \mathrm{C}$. To separate the three isomers 4-methyl-, 3-methyl-, and 2-methylvaleric acid, the temperature of the column was decreased to $100^{\circ} \mathrm{C}$.

Survival of organisms in aerated solutions. A PY/glucose broth (Holdeman \& Moore, 1975) culture of $P$. anaerobius in exponential growth phase was diluted to about $3 \times 10^{5}$ cells $\mathrm{ml}^{-1}$ in the salt solution. This suspension was brought out from the anaerobic box and $0.2 \mathrm{ml}$ was added to $1.8 \mathrm{ml}$ reaction mixture in a $50 \mathrm{ml}$ round-bottomed flask. The reaction mixtures contained salt solution and glucose, pyruvate, leucine or various combinations of these substrates and had been aerated at $37^{\circ} \mathrm{C}$ by vigorous shaking in a thermostated water bath. All reaction mixtures also contained $52 \mu \mathrm{g}$ catalase. At 0,2 and $4 \mathrm{~h}$, samples of $0.2 \mathrm{mI}$ were withdrawn from the flasks and diluted in $1.8 \mathrm{ml}$ aerated salt solution containing $5 \%(\mathrm{v} / \mathrm{v})$ haemolysed horse blood. From these dilutions, $0 \cdot 1 \mathrm{ml}$ was spread over the surface of duplicate blood agar plates which had been taken from the anaerobic box just prior to use. The plates were then immediately returned to the box and incubated for $3 \mathrm{~d}$ at $37^{\circ} \mathrm{C}$.

After counting the number of colonies on the plates, the survival in the 2 and $4 \mathrm{~h}$ samples was expressed as a percentage of the number of colonies at time 0 . The results from four independent experiments for each reaction mixture were analysed by a one-way analysis of variance procedure. The survivals in the 2 and $4 \mathrm{~h}$ samples from the different experimental conditions were then compared by a $t$ statistic evaluation.

${ }^{14} \mathrm{CO}_{2}$ release from $\left.\mathrm{D}-{ }^{14} \mathrm{C}\right]$ glucose by aerated intact organisms. Organisms were washed and suspended in $1 \mathrm{ml}$ salt solution containing $23 \mu \mathrm{g}$ catalase under anaerobic conditions. The cell suspension was taken out from the anaerobic glove box and mixed with $0.6 \mathrm{ml}$ salt solution in a Warburg vessel. The mixture was aerated by vigorous shaking in a thermostated water bath at $35^{\circ} \mathrm{C}$. After $10 \mathrm{~min}$ the reaction was started by adding $0.2 \mathrm{ml} 0 \cdot 1 \mathrm{M}-\mathrm{D}-\left[{ }^{14} \mathrm{C}\right]$ glucose, and was stopped after $40 \mathrm{~min}$ by adding $0.2 \mathrm{ml} 50 \%(\mathrm{w} / \mathrm{v})$ perchloric acid. Released ${ }^{14} \mathrm{CO}_{2}$ was absorbed into $0.2 \mathrm{ml} 20 \%(\mathrm{w} / \mathrm{v}) \mathrm{KOH}$ in the centre well of the vessel and converted to $\mathrm{Ba}^{14} \mathrm{CO}_{3}$, the radioactivity of which was determined in a scintillation counter as described previously (Hoshino et al., 1976).

Assay of $\mathrm{H}_{2}$ and $\mathrm{CO}_{2}$ formation by intact organisms. Organisms $\left(1.8 \times 10^{12}\right)$ were washed and suspended in $30 \mathrm{ml} 50 \mathrm{~mm}$-potassium phosphate buffer ( $\mathrm{pH} 7.5)$ in the anaerobic glove box. The cell suspension was taken out from the box in rubber-stoppered $15 \mathrm{ml}$ tubes with $10 \mathrm{ml}$ in each tube and oxygen-free nitrogen was bubbled through for $20 \mathrm{~min}$. Then $80 \mathrm{mg}$ glucose was added to one tube and $100 \mathrm{mg}$ pyruvate to another tube and these two tubes, together with one to which no further additions were made, were incubated at $37^{\circ} \mathrm{C}$ overnight. After incubation the tubes were heated at $100^{\circ} \mathrm{C}$ for $5 \mathrm{~min}$. The gas in the dead space was collected in a well-greased syringe and its composition was determined by gas chromatography (Czerkawski \& Clapperton, 1968). Using a gas sampling valve, $0.5 \mathrm{ml}$ samples were passed through a copper column $(70 \times 0.6 \mathrm{~cm})$ containing Porapak $\mathrm{Q}(50 / 80 \mathrm{mesh})$ at $62{ }^{\circ} \mathrm{C}$ and then through the thermal conductivity detector at $100^{\circ} \mathrm{C}$. The gas then passed through an empty Teflon tube $(80 \times 0.16 \mathrm{~cm})$, through a copper column $(180 \times 0.6 \mathrm{~cm})$ containing molecular sieve $5 \mathrm{~A}$ at ambient temperature and again through the thermal conductivity detector at $100^{\circ} \mathrm{C}$.

Assay of oxygen consumption by intact organisms. Organisms $\left(6 \times 10^{10}\right)$ were washed and suspended in $1 \mathrm{ml}$ salt solution. The cell suspension was taken out from the anaerobic box in a rubber-stoppered tube, mixed with $1 \mathrm{ml}$ aerated salt solution in a biological oxygen monitor (model 53; Yellow Springs Instruments Co., Yellow Springs, Ohio, U.S.A.) and the oxygen consumption was followed polarographically. After measuring the initial rate of oxygen consumption, the suspension was aerated each time the oxygen concentration decreased below $50 \%$ saturation. Oxygen consumption was also followed in the presence of $5 \mathrm{~mm}$-glucose, 5 mm-leucine or $50 \mu \mathrm{g}$ catalase. The electrode was calibrated according to Robinson \& Cooper (1970).

Preparation of the crude cell-free extract. Organisms were grown in trypticase soy broth or in TYC medium (Griffith \& Carlsson, 1974), harvested by centrifugation, washed twice with $40 \mathrm{~mm}$-potassium phosphate buffer ( $\mathrm{pH} 7.0$ ) and disintegrated in a homogenizer (type MSK; Braun, Melsungen, Germany) for 1 min under $\mathrm{CO}_{2}$ gas cooling (Yamada \& Carlsson, 1975). After removing cell debris by centrifugation ( $40000 \mathrm{~g}$, $30 \mathrm{~min}, 4^{\circ} \mathrm{C}$ ), the supernatant fluid $(2$ to $10 \mathrm{ml}$ ) was dialysed overnight against 1 litre $40 \mathrm{~mm}$-potassium phosphate buffer $\left(\mathrm{pH} 7 \cdot 0,4^{\circ} \mathrm{C}\right)$. All preparations were protected from exposure to oxygen during all stages of the work. Protein concentration was determined as described by Lowry et al. (1951).

Partial purification of ' $N A D H$ oxidase'. Solid ammonium sulphate was added in small portions with stirring to $10 \mathrm{ml}$ of the crude cell-free extract. The material precipitated at 50 to $80 \%(\mathrm{w} / \mathrm{v})$ ammonium sulphate saturation was dialysed overnight against 1 litre $10 \mathrm{~mm}-\mathrm{Tris} / \mathrm{HCl}$ buffer $(\mathrm{pH} \mathrm{7.0)}$ and passed through a CM-cellulose column $(4.5 \times 0.5 \mathrm{~cm})$ equilibrated with similar buffer. The enzyme was then adsorbed on to a DEAE-cellulose column $(4.5 \times 0.5 \mathrm{~cm})$ equilibrated with similar buffer. The column was washed with $10 \mathrm{mM}$-Tris/ $\mathrm{HCl}$ buffer $(\mathrm{pH} \mathrm{7.0)}$ and $10 \mathrm{~mm}$-potassium phosphate buffer $(\mathrm{pH} \mathrm{6.0)}$ and eluted with $4 \mathrm{ml}$ portions of $50 \mathrm{~mm}$-potassium phosphate buffer $(\mathrm{pH} \mathrm{6.0)}$ containing increasing concentrations of $\mathrm{KCl}(50,100,200$ and $300 \mathrm{~mm})$. The degree of purification of the 'NADH oxidase' by this procedure was 38- to 56-fold. 
Assay of oxygen consumption and hydrogen peroxide formation by the crude cell-free extract. Oxygen consumption was followed in the biological oxygen monitor. An increase in oxygen concentration after addition of $6 \mu \mathrm{g}$ catalase indicated that hydrogen peroxide was present in the reaction mixture. By comparing this increase with that caused by subsequent addition of a standard amount of hydrogen peroxide, the concentration of hydrogen peroxide in the reaction mixture at the time of catalase addition could be calculated. The concentration of hydrogen peroxide in the standard solution was determined by measuring $A_{240}\left(\varepsilon_{\mathrm{mm}} 43 \cdot 2\right)$.

Assay of the reduction of cytochrome $c$. The rate of reduction was estimated from the increase in $A_{550}$ $\left(\epsilon_{\mathrm{ma}} 19 \cdot 1\right.$; Minakami et al., 1962) under aerobic conditions.

Assay of the oxidation of NADH and NADPH by the crude cell-free extract. The rate of oxidation of NADH and NADPH in the presence of oxygen ('NADH and NADPH oxidase' activity) was measured spectrophotometrically at $340 \mathrm{~nm}\left(\epsilon_{\mathrm{mm}} 6 \cdot 22\right)$. The rate of reduction of electron acceptor in the presence of NADH or NADPH under anaerobic conditions was measured spectrophotometrically at $405 \mathrm{~nm}$ for ferricyanide $\left(\epsilon_{\mathrm{mm}} 1.04\right.$; Boll, 1968), at $600 \mathrm{~nm}$ for 2,6-dichlorophenolindophenol (DCPIP) $\left(\epsilon_{\mathrm{mM}} 21\right.$; King \& Howard, 1967) and at $450 \mathrm{~nm}$ for FAD $\left(\epsilon_{\mathrm{mx}} 11 \cdot 3\right.$; Dolin, 1957). The specific activity was expressed as nmol substrate oxidized $\mathrm{min}^{-1}$ (mg protein) ${ }^{-1}$, considering ferricyanide as a one-electron equivalent oxidant and DCPIP (King \& Howard, 1967) and FAD as two-electron equivalent oxidants.

Assay of the peroxidation of NADH and NADPH. No peroxidase (donor:hydrogen-peroxide oxidoreductase, EC 1.11 .1 .7) could be detected in the cell-free extract of $P$.anaerobius VPI4330-1 with the guaiacol method (Bergmeyer et al., 1970). The peroxidation of NADH and NADPH was measured spectrophotometrically at $340 \mathrm{~nm}$ under anaerobic conditions in a reaction mixture $(2 \mathrm{ml})$ containing: $100 \mu \mathrm{mol}$ potassium phosphate buffer (pH 7.5) or acetate buffer (pH 5.4), $180 \mathrm{nmol} \mathrm{NADH}$ or $125 \mathrm{nmol}$ NADPH, $1.84 \mu \mathrm{mol}$ $\mathrm{H}_{2} \mathrm{O}_{2}$ and the crude cell-free extract.

Assay of other enzyme activities in crude cell-free extract. Glyceraldehyde-3-phosphate dehydrogenase [D-glyceraldehyde-3-phosphate:NAD ${ }^{+}$oxidoreductase (phosphorylating), EC 1.2.1.12], glucose-6phosphate dehydrogenase (D-glucose-6-phosphate:NADP+ 1-oxidoreductase, EC 1.1.1.49), phosphogluconate dehydrogenase [6-phospho-D-gluconate:NADP+ 2-oxidoreductase (decarboxylating), EC 1.1.1 .44], lactate dehydrogenase (L-lactate: $\mathrm{NAD}^{+}$oxidoreductase, EC 1.1.1.27), D-lactate dehydrogenase (D-lactate: $\mathrm{NAD}^{+}$oxidoreductase, EC 1.1.1.28), alanine aminotransferase (L-alanine:2-oxoglutarate aminotransferase, $\mathrm{EC} 2.6 .1 .2$ ), glutamate dehydrogenase [L-glutamate: $\mathrm{NAD}^{+}$oxidoreductase (deaminating), EC 1.4.1.2], glutamate dehydrogenase $\left(\mathrm{NADP}^{+}\right)$[L-glutamate: $\mathrm{NADP}^{+}$oxidoreductase (deaminating), EC 1.4.1.4] and alcohol dehydrogenase (alcohol:NAD ${ }^{+}$oxidoreductase, EC 1.1.1.1) were assayed as described by Bergmeyer et al. (1970). Glutamate dehydrogenase was also assayed as described by Bernt $\&$ Bergmeyer (1965). Aldehyde dehydrogenase (acylating) [aldehyde:NAD ${ }^{+}$oxidoreductase (CoA-acylating), EC 1.2.1.10] was assayed by the decrease in absorbance at $340 \mathrm{~nm}$ in a reaction mixture with $0.6 \mathrm{~mm}$ NADH and $1.2 \mathrm{~mm}$-acetyl-CoA in $0.2 \mathrm{M}$-Tris/HCl buffer (pH 8.1). Aldehyde dehydrogenase (NADP ${ }^{+}$) [aldehyde:NADP ${ }^{+}$oxidoreductase, EC 1.2.1.4] was assayed as described by Seegmiller (1955). L-Aminoacid oxidase [L-amino-acid:oxygen oxidoreductase (deaminating), EC 1.4.3.2] and D-amino-acid oxidase [D-amino-acid: oxygen oxidoreductase (deaminating), EC 1.4.3.3] were measured with an oxygen electrode (Boulanger \& Osteux, 1965). Formate dehydrogenase (formate:NAD ${ }^{+}$oxidoreductase, EC 1.2.1.2) was assayed as described by Andreesen \& Ljungdahl (1974) with NAD as well as with NADP. All activities were assayed under anaerobic conditions at $25^{\circ} \mathrm{C}$.

\section{RESULTS}

\section{Fermentation products under aerobic and anaerobic conditions}

The main fermentation products of $P$. anaerobius vPI4330-1 growing under anaerobic conditions in trypticase soy broth or in PY/glucose broth were ethanol, acetate and 4-methylvalerate.

Under anaerobic conditions, no fermentation products were formed from glucose by a resting-cell suspension. From pyruvate, the organisms produced acetate and ethanol, and they converted leucine into 4-methylvalerate (Fig. 1). When both pyruvate and leucine were included in the reaction mixture, the rate of production of acetate and 4-methylvalerate increased and that of ethanol decreased (Fig. 2). The final lactate concentration in the cell suspension never exceeded $0.2 \mathrm{~mm}$.

Under aerobic conditions, the organisms produced acetate from glucose as well as from pyruvate. Some acetate was also formed without added substrate (Fig. 1). Ethanol was 

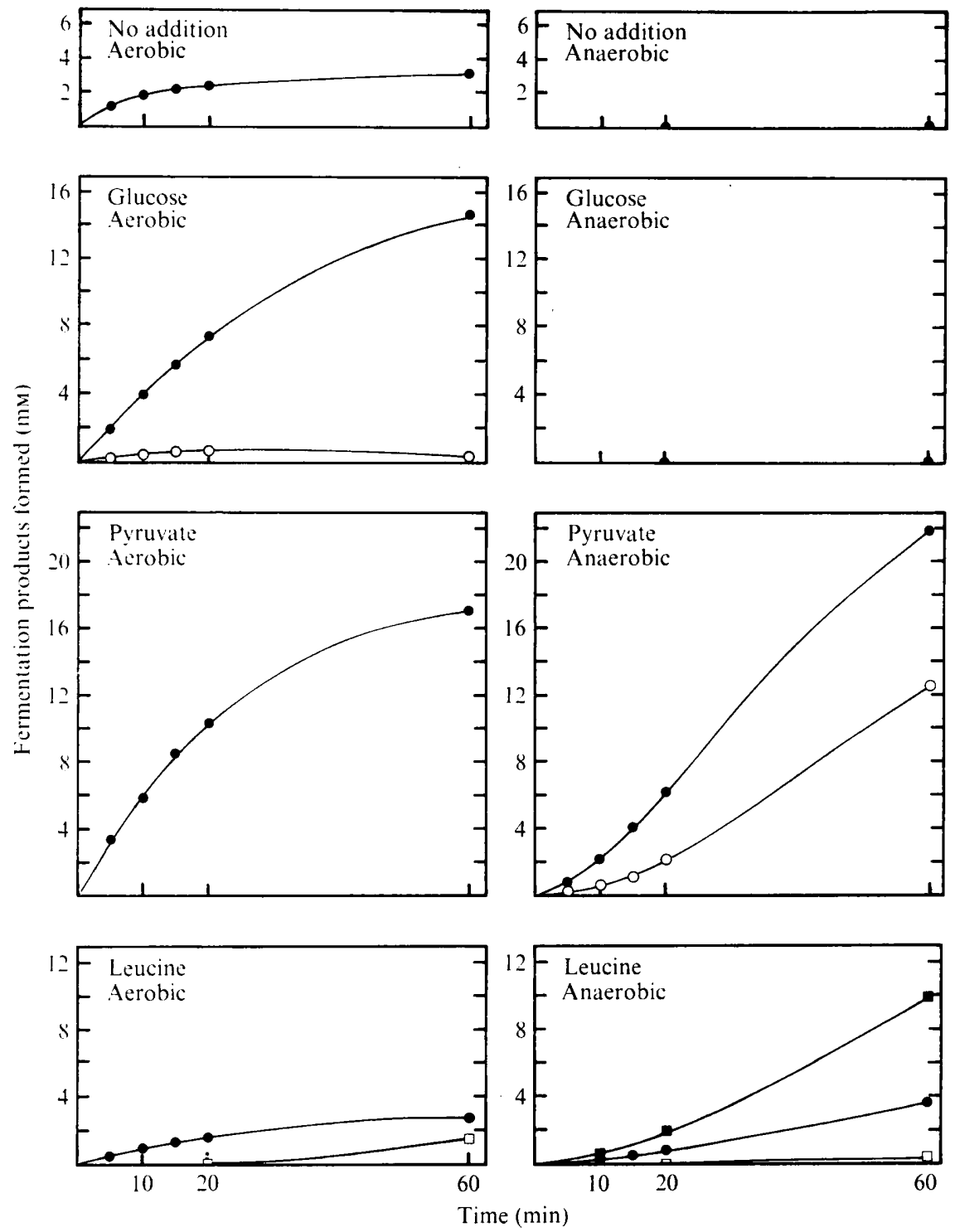

Fig. 1. Fermentation products formed under aerobic and anaerobic conditions by a resting-cell suspension of $P$. anaerobius VPI4330-1 at $37^{\circ} \mathrm{C}$ in a salt solution supplemented with various substrates (as indicated) and $26 \mu \mathrm{g}$ catalase $\mathrm{ml}^{-1}$. The concentrations of the substrates are given in Table 1. ๑, Acetate; $O$, ethanol; $\square, 4$-methylvalerate; $\square, \alpha$-ketoisocaproate.

only formed from glucose and in low concentration (Fig. 1). Leucine was converted into $\alpha$-ketoisocaproic acid (Fig. 1).

Under anaerobic conditions, $\mathrm{CO}_{2}$ and $\mathrm{H}_{2}$ were produced from pyruvate and $\mathrm{CO}_{2}$ from glucose.

\section{Survival in aerated resting-cell suspension}

Peptostreptococcus anaerobius vPI4330-1 survived for $4 \mathrm{~h}$ in an aerated salt solution containing catalase (Table 1). The organisms also survived when this catalase/salt solution was supplemented with pyruvate, pyruvate plus leucine or glucose plus leucine. A significant decrease in the number of living organisms after $4 \mathrm{~h}$ was found when they were incubated with glucose or with leucine (Table 1). 


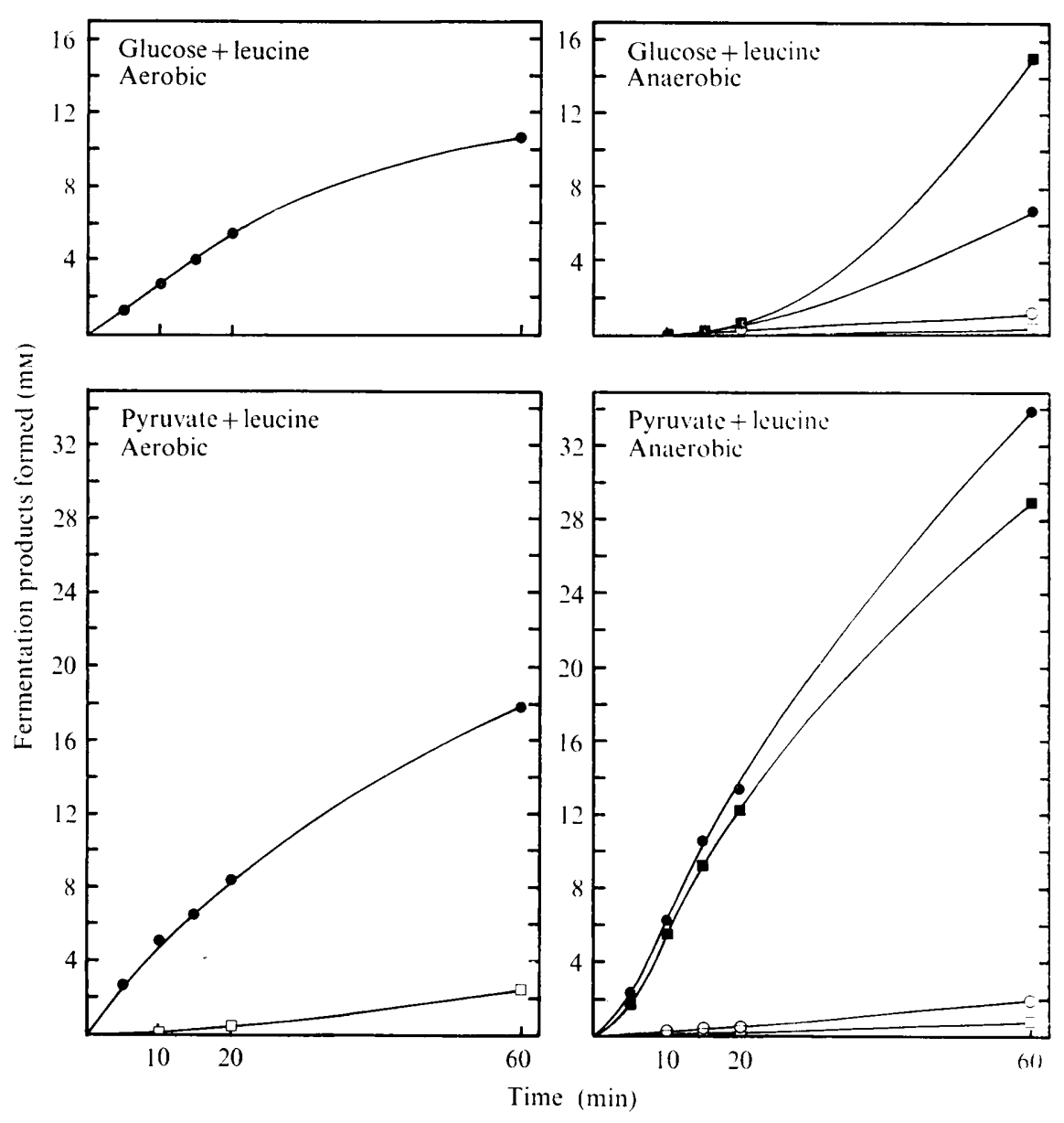

Fig. 2. Fermentation products formed under aerobic and anaerobic conditions by a resting-cell suspension of $P$. anaerobius vPI4330-1 at $37{ }^{\circ} \mathrm{C}$ in a salt solution supplemented with various substrates (as indicated) and $26 \mu \mathrm{g}$ catalase $\mathrm{ml}^{-1}$. The concentrations of the substrates are given in Table 1. ๑, Acetate; $\bigcirc$, ethanol; $\mathbf{n}, 4$-methylvalerate; $\square, \alpha$-ketoisocaproate.

\section{Oxygen consumption by intact organisms}

When organisms $\left(6 \times 10^{10}\right)$ were exposed to oxygen in $2 \mathrm{ml}$ aerated salt solution, oxygen

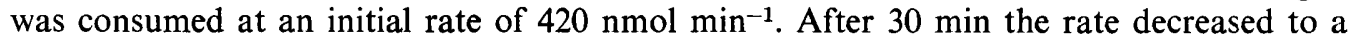
constant value of $24 \mathrm{nmol} \mathrm{min}{ }^{-1}$. Addition of glucose $(5 \mathrm{mM})$ to the reaction mixture increased the rate to $43 \mathrm{nmol} \mathrm{min}^{-1}$. The oxygen consumption was not changed by the addition of leucine $(5 \mathrm{~mm})$. No hydrogen peroxide was detected in the reaction mixture.

\section{Oxygen consumption by the crude cell-free extract}

Oxygen was consumed when the crude cell-free extract of $P$. anaerobius VPI4330-1 was incubated with NADH or NADPH (Table 2). No oxygen was consumed without NADH, NADPH or the crude cell-free extract in the reaction mixture. Under anaerobic conditions, NADH and NADPH were also oxidized by ferricyanide, DCPIP and FAD, but not by fumarate or leucine (Table 2). Oxygen was as efficient an electron acceptor as ferricyanide and DCPIP in NADH oxidation, but was a less efficient electron acceptor than ferricyanide and DCPIP in NADPH oxidation (Table 2). NADH and NADPH were not oxidized under anaerobic conditions if no electron acceptor was added to the reaction mixture.

Oxygen was consumed at a rate of $4 \cdot 3 \mathrm{nmol} \mathrm{min}{ }^{-1}(\mathrm{mg} \text { protein })^{-1}$ when the crude extract 


\section{Table 1. Survival of P. anaerobius VPI4330-1 in an aerated resting-cell suspension}

The organisms were suspended in the salt solution containing $26 \mu \mathrm{g}$ catalase $\mathrm{ml}^{-1}$ and supplemented with glucose $(20 \mathrm{~mm})$, pyruvate $(40 \mathrm{~mm})$, L-leucine $(40 \mathrm{~mm})$ or various mixtures of these substrates. Means and standard deviations from four independent experiments are given.

\begin{tabular}{lcc} 
& \multicolumn{2}{c}{$\begin{array}{c}\text { Percentage of cells } \\
\text { surviving after: }\end{array}$} \\
\cline { 2 - 3 } Addition & $2 \mathrm{~h}$ & $4 \mathrm{~h}$ \\
None & $103 \pm 11$ & $106 \pm 6$ \\
Glucose & $68 \pm 13$ & $66 \pm 15$ \\
Pyruvate & $91 \pm 11$ & $91 \pm 11$ \\
L-Leucine & $83 \pm 10$ & $72 \pm 11$ \\
Glucose + L-leucine & $91 \pm 13$ & $88 \pm 18$ \\
Pyruvate+L-Jeucine & $89 \pm 8$ & $94 \pm 19$
\end{tabular}

Table 2. Oxidation of NADH and NADPH by crude cell-free extract of P. anaerobius VPI4330-1 in the presence of various electron acceptors at $25^{\circ} \mathrm{C}$

The reaction mixture $(2 \mathrm{ml})$ contained: $100 \mu \mathrm{mol}$ potassium phosphate buffer $(\mathrm{pH} 7 \cdot 5), 180 \mathrm{nmol}$ $\mathrm{NADH}$ or $125 \mathrm{nmol}$ NADPH and $0.1 \mathrm{mg}$ cell-free extract protein. Under anaerobic conditions an electron acceptor was added; under aerobic conditions the reaction mixture was saturated with atmospheric oxygen $(245 \mu \mathrm{M})$. Specific activities are expressed as nmol pyridine nucleotide converted $\min ^{-1}$ (mg protein $)^{-1}$.

\begin{tabular}{|c|c|c|c|}
\hline Donor & Acceptor & $\begin{array}{c}\text { Gas } \\
\text { phase }\end{array}$ & $\begin{array}{l}\text { Specific } \\
\text { activity }\end{array}$ \\
\hline NADH & Oxygen & Aerobic & 127 \\
\hline NADPH & Oxygen & Aerobic & 23 \\
\hline NADH & $0.5 \mathrm{~mm}$-Ferricyanide & Anaerobic & 101 \\
\hline NADPH & $0.5 \mathrm{~mm}$-Ferricyanide & Anaerobic & 324 \\
\hline NADH & 0.06 mм-DCPIP* & Anaerobic & 63 \\
\hline NADPH & 0.06 mм-DCPIP & Anaerobic & 150 \\
\hline NADH & $0.08 \mathrm{~mm}-\mathrm{FAD}$ & Anaerobic & 18 \\
\hline NADPH & 0.08 mM-FAD & Anaerobic & 2 \\
\hline $\mathrm{NADH}$ & 5 mm-Fumarate & Anaerobic & 0 \\
\hline NADPH & 5 mm-Fumarate & Anaerobic & 0 \\
\hline NADH & 5 mM-L-Leucine & Anaerobic & 0 \\
\hline NADPH & 5 mm-L-Leucine & Anaerobic & 0 \\
\hline
\end{tabular}

was incubated together with $9 \mathrm{~mm}$-alanine, $2.5 \mathrm{~mm}$-2-oxoglutarate and $0.3 \mathrm{~mm}$-NAD. All three components were required for the oxygen consumption. NADP could not substitute for NAD. Oxygen was also consumed when the crude extract was incubated with glutamate and NAD. Alanine aminotransferase activity $\left[88 \mathrm{nmol} \mathrm{min}^{-1}(\mathrm{mg} \text { protein })^{-1}\right.$ ] and NAD-dependent glutamate dehydrogenase activity (Table 5) were present.

Oxygen was not consumed when the crude cell-free extract was incubated with $(5 \mathrm{~mm})$ glucose, galactose, fructose, pyruvate, lactate, ethanol, malate or aspartate or $(9 \mathrm{~mm})$ glycine, cysteine, tyrosine, arginine, alanine, valine, leucine, isoleucine, methionine, tryptophan, phenylalanine, proline, norvaline, norleucine, histidine or threonine.

\section{Hydrogen peroxide and superoxide radicals formed by the crude cell-free extract}

Under aerobic conditions, NADH was oxidized by the crude cell-free extract at 127 nmol $\mathrm{min}^{-1}$ (mg protein) $)^{-1}$ (Table 2) and oxygen was consumed at $70 \mathrm{nmol} \mathrm{min}{ }^{-1}$ (mg

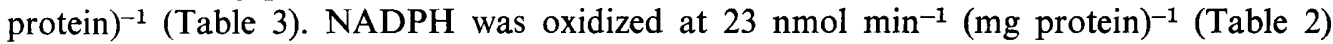
with an accompanying oxygen consumption of $20 \mathrm{nmol} \mathrm{min}^{-1}$ (mg protein) ${ }^{-1}$ (Table 3). This suggested that for each mol oxygen consumed, $2 \mathrm{~mol} \mathrm{NADH}$ or $1 \mathrm{~mol} \mathrm{NADPH}$ was oxidized. 
Table 3. The rate of oxygen consumption and the formation of hydrogen peroxide by crude cell-free extract of $P$. anaerobius VPI4330-1 in the presence of NADH and NADPH at $25^{\circ} \mathrm{C}$

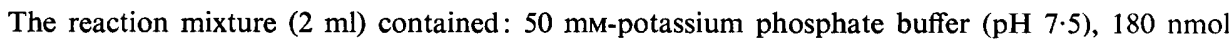
$\mathrm{NADH}$ and $0.62 \mathrm{mg}$ cell-free extract protein for NADH oxidation or $225 \mathrm{nmol}$ NADPH and $1.3 \mathrm{mg}$ protein for NADPH oxidation. The initial rate of oxygen consumption is expressed as $\mathrm{nmol} \mathrm{min}^{-1}$ (mg protein) $)^{-1}$. Two min after the start of the reaction, $6 \mu \mathrm{g}$ catalase were added to the reaction mixture for determination of the hydrogen peroxide concentration. Means and standard deviations from three experiments are given.

\begin{tabular}{|c|c|c|c|c|}
\hline $\begin{array}{c}\text { Substrate } \\
\text { and addition }\end{array}$ & $\begin{array}{c}\text { Initial } \\
\text { rate of } \\
\text { oxygen } \\
\text { consumption }\end{array}$ & $\begin{array}{l}\text { Oxygen } \\
\text { consumed } \\
\text { (A) } \\
(\mathrm{nmol})\end{array}$ & $\begin{array}{c}\text { Hydrogen } \\
\text { peroxide } \\
\text { formed } \\
(\mathrm{B}) \\
(\mathrm{nmol})\end{array}$ & $\begin{array}{c}\text { Ratio } \\
\text { B/A }\end{array}$ \\
\hline None & 0 & 0 & 0 & 0 \\
\hline $\begin{array}{l}\text { NADH } \\
\text { NADH + SOD } \\
\text { NADH + SOD + catalase }\end{array}$ & $\begin{array}{l}70 \cdot 2 \pm 1 \cdot 8 \\
70 \cdot 0 \pm 1 \cdot 7 \\
69 \cdot 2 \pm 0 \cdot 7\end{array}$ & $\begin{array}{c}79 \pm 5 \\
78 \pm 3 \\
-\end{array}$ & $\begin{array}{l}<2 \\
5 \pm 0\end{array}$ & $\begin{array}{c}<0.03 \\
0.06 \\
-\end{array}$ \\
\hline $\begin{array}{l}\text { NADPH } \\
\text { NADPH + SOD } \\
\text { NADPH + SOD + catalase }\end{array}$ & $\begin{array}{r}20 \cdot 3 \pm 0 \cdot 7 \\
11 \cdot 5 \pm 0 \cdot 7 \\
6 \cdot 4 \pm 0 \cdot 3\end{array}$ & $\begin{array}{l}33 \pm 3 \\
30 \pm 0 \cdot 7 \\
-\end{array}$ & $\begin{array}{l}27 \pm 2 \\
29 \pm 1 \\
-\end{array}$ & $\begin{array}{l}0.8 \\
1.0 \\
-\end{array}$ \\
\hline
\end{tabular}

Almost all NADH was oxidized within 2 min. Less than $3 \%$ of the oxygen consumed was recovered as hydrogen peroxide (Table 3). In the presence of superoxide dismutase (SOD), $6 \%$ of the oxygen consumed was converted into hydrogen peroxide (Table 3 ). Catalase and SOD did not change the rate of oxygen consumption (Table 3 ). This suggested that water was the main product in this oxidation. No peroxidase activity was detected in the crude cell-free extract with hydrogen peroxide and guaiacol, NADH or NADPH as substrates.

When NADPH was oxidized, almost all oxygen consumed was converted into hydrogen peroxide (Table 3). Addition of SOD to the reaction mixture reduced the rate of oxygen consumption by about $50 \%$ and the addition of SOD and catalase reduced it further to $25 \%$ of the rate when these enzymes were not present in the reaction mixture (Table 3 ). However, SOD and catalase did not decrease the rate of NADPH oxidation when monitored at $340 \mathrm{~nm}$ (data not shown). This suggested that superoxide radicals were formed as intermediates, when oxygen was converted into hydrogen peroxide. The production of superoxide radicals was confirmed when the crude cell-free extract was incubated with NADPH and cytochrome $c$ under aerobic conditions. Cytochrome $c$ was reduced and the reduction could be inhibited by SOD (Fig. 3).

On the other hand, the rate of cytochrome $c$ reduction was very low when the cytochrome was incubated with NADH and the crude cell-free extract (Fig. 3). This reduction could be inhibited by SOD (Fig. 3). This suggested that superoxide radicals were also generated during the oxidation of NADH by the crude cell-free extract, but significantly lower amounts of these radicals were formed during NADH oxidation than during NADPH oxidation.

The rate of reduction of cytochrome $c$ during the NADH oxidation was significantly increased by adding FAD to the reaction mixture under aerobic conditions (Fig. 3). When FAD was reduced to $\mathrm{FADH}_{2}$ by the crude cell-free extract during NADH oxidation under anaerobic conditions (cf. Table 2) and $\mathrm{FADH}_{2}$ was exposed to air in the presence of cytochrome $c$, the cytochrome was reduced and the reaction was inhibited by SOD (Table 4). This suggested that superoxide radicals were generated. Each nmol $\mathrm{FADH}_{2}$ generated 1.2 to $1.4 \mathrm{nmol}$ superoxide radicals (Table 4 ). On the other hand, FAD did not increase the rate of cytochrome $c$ reduction during NADPH oxidation by more than $10 \%$ (Fig. 3 ). 


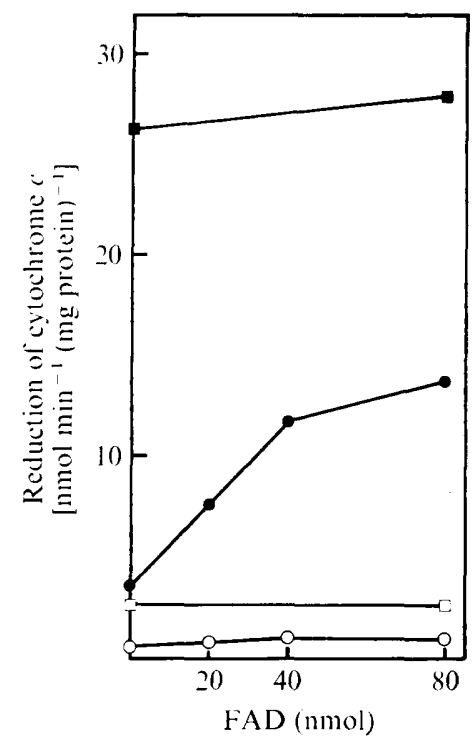

Fig. 3. Rate of reduction of cytochrome $c$ during the oxidation of NADH and NADPH by cellfree extract of $P$. anaerobius vPI4330-1 under aerobic conditions. The reaction mixture $(3 \mathrm{ml})$ contained: $200 \mu \mathrm{mol}$ potassium phosphate buffer ( $\mathrm{pH} 8 \cdot 0$ ), $46 \cdot 2 \mathrm{nmol}$ cytochrome $c, 0 \cdot 22 \mathrm{mg}$ crude cell-free extract protein and FAD as indicated., $180 \mathrm{nmol} \mathrm{NADH} ; \mathrm{O}, 180 \mathrm{nmol} \mathrm{NADH}+$ $33 \mu \mathrm{g}$ SOD; $\mathbf{\square}, 180 \mathrm{nmol}$ NADPH; $\square, 180 \mathrm{nmol} \mathrm{NADPH}+33 \mu \mathrm{g}$ SOD.

\section{Table 4. Reduction of cytochrome c following the oxidation of $\mathrm{FADH}_{2}$ under aerobic conditions}

Experiment A: FAD was reduced enzymically under anaerobic conditions in a reaction mixture $(2 \mathrm{ml})$ containing: $100 \mu \mathrm{mol}$ potassium phosphate buffer $(\mathrm{pH} 7 \cdot 5$ ), 80 nmol FAD, $0.55 \mathrm{mg}$ cellfree extract protein, $6 \mu \mathrm{g}$ catalase and NADH. After all the NADH was oxidized, $0.5 \mathrm{ml}$ of the reaction mixture with or without $30 \mu \mathrm{g}$ SOD (as indicated) was transferred to $2.5 \mathrm{ml}$ of an aerated cytochrome $c$ solution containing: $100 \mu \mathrm{mol}$ potassium phosphate buffer (pH 8.0), 46 nmol cytochrome $c$ and $6 \mu \mathrm{g}$ catalase. The reduction of cytochrome $c$ was measured spectrophotometrically at $550 \mathrm{~nm}$.

Experiment B: FAD was reduced in the anaerobic glove box by hydrogen bubbling in the presence of palladium asbestos as catalyst in $50 \mathrm{~mm}$-potassium phosphate buffer (pH 7.5) containing $3 \mu \mathrm{g}$ catalase $\mathrm{ml}^{-1}$. After FAD was reduced, $0.5 \mathrm{ml}$ of the reaction mixture was transferred to $2.5 \mathrm{ml}$ of the aerated cytochrome $c$ solution.

\section{NADH oxidized (nmol)}

A.

$4 \cdot 5$
9
18
36
36
54
72
72

B.
FAD reduced (nmol)

4
9
20
38
$38+$ SOD
49
58
$58+$ SOD

26

20

$20+$ SOD

42

\section{Cytochrome $c$ reduced (nmol)}


Table 5. NAD- and NADP-dependent enzyme activities in crude cell-free extract of $P$. anaerobius VPI4330-1 measured under anaerobic conditions at $25^{\circ} \mathrm{C}$

Specific activities are expressed as nmol pyridine nucleotide converted $\min ^{-1}$ (mg protein) ${ }^{-1}$.

\section{Enzyme}

Glyceraldehyde-3-phosphate dehydrogenase (EC 1.2.1.12)

Glyceraldehyde-3-phosphate dehydrogenase (EC 1.2.1.13)

Alcohol dehydrogenase (EC 1.1.1.1)

Glutamate dehydrogenase (EC 1.4.1.2)

Glucose-6-phosphate dehydrogenase (EC 1.1.1.49)

Phosphogluconate dehydrogenase (EC 1.1.1.44)

Formate dehydrogenase (EC 1.2.1.2)

Formate dehydrogenase

Aldehyde dehydrogenase (acylating) (EC 1.2.1.10)

Aldehyde dehydrogenase (NADP ${ }^{+}$) (EC 1.2.1.4)

Lactate dehydrogenase (EC 1.1.1.27 and 1.1.1.28)

\section{Pyridine \\ nucleotide}

NAD
NADP
NAD
NAD
NADP
NADP
NAD
NADP
NADH
NADP
NADH
Specific activity

33

$<0.01$

9

155

10

14

$<0.01$

$<0.01$

2

$<0.01$

199

Table $6 .{ }^{14} \mathrm{CO}_{2}$ release from $\mathrm{D}-\left[{ }^{14} \mathrm{C}\right]$ glucose by washed organisms of $P$. anaerobius VPI4330-1 in an aerated salt solution during 30 min incubation at $35^{\circ} \mathrm{C}$

The specific activity of $\mathrm{D}$-glucose was $0.1 \mathrm{mCi} \mathrm{mmol}^{-1}$. The released ${ }^{14} \mathrm{CO}_{2}$ was absorbed into $\mathrm{KOH}$ in the centre well of a Warburg vessel, converted into $\mathrm{Ba}^{14} \mathrm{CO}_{3}$ and the radioactivity was determined in a scintillation counter. The number of organisms in Expt 1 was $1 \cdot 5 \times 10^{10}$ and in Expt 2 was $3 \times 10^{10}$.

\begin{tabular}{lrc} 
& \multicolumn{2}{c}{ Radioactivity (c.p.m.) } \\
Substrate & Expt 1 & Expt 2 \\
D-[1-14 C]Glucose & 9991 & 14634 \\
D-[6-14 C]Glucose & 1499 & 2178 \\
D-[U-14 C]Glucose & 24881 & NT \\
& NT, Not tested.
\end{tabular}

Cytochrome $c$ was not reduced when partially purified 'NADH oxidase', instead of the crude cell-free extract, was incubated under aerobic conditions with NADH and cytochrome $c$; neither was any hydrogen peroxide formed.

\section{$N A D$ - and NADP-dependent enzymic activities in the crude cell-free extract}

NAD-dependent glyceraldehyde-3-phosphate dehydrogenase, alcohol dehydrogenase, lactate dehydrogenase and glutamate dehydrogenase activities were demonstrated in the crude cell-free extract (Table 5). No NAD- or NADPH-dependent formate dehydrogenase activity was detected. Formate was not produced from pyruvate, and formate was not consumed by the resting organisms. NADP-dependent glucose-6-phosphate dehydrogenase and phosphogluconate dehydrogenase activities were also found in the crude cell-free extract (Table 5).

Aldehyde dehydrogenase (acylating) activity, but not aldehyde dehydrogenase (NADP ${ }^{+}$) activity, was detected in the crude cell-free extract (Table 5).

\section{Release of $\mathrm{CO}_{2}$ from glucose}

When $\left[{ }^{14} \mathrm{C}\right]$ glucose was incubated with washed organisms, ${ }^{14} \mathrm{CO}_{2}$ release from $\left[1-{ }^{14} \mathrm{C}\right]-$ glucose was six times higher than from $\left[6-{ }^{14} \mathrm{C}\right]$ glucose (Table 6$) .{ }^{14} \mathrm{CO}_{2}$ release from $\left[1-{ }^{14} \mathrm{C}\right]-$ glucose was only about $7 \%$ of that from $\left[\mathrm{U}-{ }^{14} \mathrm{C}\right]$ glucose.

$$
\{(9991 / 6) /[24881-(9991 / 6)]\} \times 100=7 \cdot 2
$$


This suggested that the hexose monophosphate pathway was involved in the degradation of glucose but only a small portion of glucose was metabolized through that pathway.

\section{DISCUSSION}

Peptostreptococcus anaerobius VPI4330-1 is an anaerobic organism in which no superoxide dismutase, catalase (Frölander \& Carlsson, 1977) or peroxidase activities have been detected. It is rapidly killed by products formed in the presence of oxygen in anaerobic media. The organism could be effectively protected from these toxic products by adding catalase to the media (Frölander \& Carlsson, 1977). The present study shows that oxygen reacted with the cellular contents of the organism and interfered with its metabolism. The results indicate that the main intracellular product of oxygen reactions was water, and deleterious products such as superoxide radicals and hydrogen peroxide were only formed to a limited extent. This may explain the high oxygen tolerance of the organism in the presence of exogenously added catalase.

The effect of oxygen on the metabolism of the organism was demonstrated by the fact that glucose and pyruvate were broken down more rapidly by a washed-cell suspension under aerobic conditions than under anaerobic conditions. There were also significant differences in metabolic end-products between these two conditions. Ethanol was only formed in significant amount under anaerobic conditions, and leucine was converted into 4-methylvaleric acid under anaerobic conditions and into $\alpha$-ketoisocaproic acid under aerobic conditions. Glucose was rapidly fermented under aerobic conditions but not at all under anaerobic conditions. This inability of the washed organisms to ferment glucose cannot yet be explained, but it has been reported that washing of another anaerobic organism, Fusobacterium polymorphum, resulted in leakage of several coenzymes (Coles, 1975) and made it unable to ferment glucose under anaerobic as well as under aerobic conditions (Coles, 1977). Its ability to ferment glucose could be restored by adding NAD, AMP and $\mathrm{Mg}^{2+}$ to the organism (Coles, 1977).

The absence of ethanol under aerobic conditions as a metabolic end-product indicates that NADH in $P$. anaerobius was oxidized by oxygen and the NADH-dependent alcohol dehydrogenase was then unable to form ethanol. Leucine was deaminated and reduced to 4-methylvaleric acid under anaerobic conditions and obviously could serve as an alternative electron sink in the cell. This pathway was preferred to ethanol production under anaerobic conditions, but the pathway was not working under aerobic conditions.

These results conclusively show that oxygen reacted with intracellular components of $P$. anaerobius and that the organisms were not killed despite the lack of protecting enzymes like superoxide dismutase, catalase and peroxidase. The reason for the excellent survival of this organism in an aerobic environment seems to be explained by the characteristics of its NADH oxidase activity. In crude cell-free extract, the oxidation of NADH by oxygen resulted in water as the main product and only small amounts of superoxide radicals and hydrogen peroxide were formed. When the NADH oxidase of the crude extract was partially purified, oxygen was reduced to water and no superoxide radicals or hydrogen peroxide were released in the reaction.

NADH oxidases are usually known as hydrogen peroxide-producing enzymes (Dolin, 1953; Anders et al., 1970; Low \& Zimkus, 1973). In some organisms the hydrogen peroxide is converted to water by an NADH peroxidase (Dolin, 1955; Mizushima \& Kitahara, 1962; Walker \& Kilgour, 1965; Dolin, 1977). NADH oxidases producing water directly have been described in Clostridium perfringens (Dolin, 1959), in Streptococcus faecalis (Hoskins et al., 1962) and in Leuconostoc mesenteroides (Kawai et al., 1971). Micro-organisms having water-producing NADH oxidases may have definite survival advantage on exposure to oxygen over those organisms that have NADH oxidases producing hydrogen peroxide (Dolin, 1959). A possible role of $\mathrm{NADH}$ oxidase in protecting anaerobic bacteria against 
the toxic effects of oxygen has been indicated by studies of Bifidobacterium strains (de Vries \& Stouthamer, 1969) and of Clostridium acetobutylicum (O'Brien \& Morris, 1971). Recently, Pritchard et al. (1977) demonstrated that NADH oxidase in Propionibacterium shermanii was inactivated when a toxic level of oxygen was reached in a continuous culture of that organism. This focuses interest on the characteristics of NADH oxidases and peroxidases of organisms with different tolerance to oxygen. So far very little is known about these enzymes.

The present study supports a conclusion that the anaerobic organism $P$. anaerobius could survive exposure to oxygen because oxygen reacted intracellularly, mainly with NADH, and the end-product of this reaction was water. However, toxic products could be produced by the cell-free extracts. There was an NADH-dependent FAD reductase activity and superoxide radicals were produced when the reduced FAD reacted with oxygen. It is possible that the small amount of superoxide radicals formed in the crude cell-free extract upon NADH oxidation was due to some free FAD in the preparation. There was also NADPH oxidase activity which reduced oxygen into superoxide radicals and hydrogen peroxide. The relative importance of the NADH and NADPH oxidases in the toxic effect of oxygen may depend on the amount of NADH and NADPH available in the organism when it is exposed to oxygen. Reduced NAD was produced by NAD-dependent glyceraldehyde-3-phosphate dehydrogenase and the level of reduced NAD in the cytoplasm might be influenced by the activities of NAD-dependent lactate, aldehyde and glutamate dehydrogenases. Reduced NADP was produced in the hexose monophosphate pathway by NADP-dependent glucose-6-phosphate and phosphogluconate dehydrogenases. However, the experiment with specifically labelled glucose showed that under the conditions of the present study, only a small fraction of glucose was degraded through the hexose monophosphate pathway.

In contrast to the findings of a previous study (Frölander \& Carlsson, 1977), catalase did not fully protect the organism in a salt solution supplemented with glucose. There were some differences in the experimental conditions between these two studies. Whether or not these differences are significant has not been elucidated. It has to be concluded, however, that the death of $P$. anaerobius in an aerobic environment in the presence of glucose and catalase is insignificant compared to the death of this organism when it is exposed to oxygen in broth media (Frölander \& Carlsson, 1977). The killing effect of intracellular reactions with oxygen is of minor importance compared to the killing effect of products formed in oxygen-exposed anaerobic media.

This study was supported by the Swedish Medical Research Council (project no. 4977).

\section{REFERENCES}

Anders, R. F., Hogg, D. M. \& JAGo, G. R. (1970). Formation of hydrogen peroxide by group $N$ streptococci and its effect on their growth and metabolism. Applied Microbiology 19, 608612.

AndReesen, J. R. \& Ljungdahl, L. G. (1974). Nicotinamide adenine dinucleotide phosphatedependent formate dehydrogenase from Clostridium thermoaceticum: purification and properties. Journal of Bacteriology 120, 6-14.

Bartlett, J. G., Sullivan-Sigler, N., Louie, T. J. \& GoRBACH, S. L. (1976). Anaerobes survive in clinical specimens despite delayed processing. Journal of Clinical Microbiology 3, 133-136.

Bergmeyer, H. U., Gawehn, K. \& Grassl, M. (1970). Die biochemischen Reagentien. I. Enzyme. In Methoden der Enzymatischen Analyse, 2nd edn, pp. 388-483. Edited by H. U. Bergmeyer. Weinheim, Germany: Verlag Chemie.

BERNT, E. \& BERGMEYER, H. U. (1965). L-Glutamate determination with glutamic dehydrogenase. In Methods of Enzymatic Analysis, pp. 384-388. Edited by H. U. Bergmeyer. New York: Academic Press.

Boll, M. (1968). Oxydation von reduziertem Nikotinamid-Adenin-Dinucleotid in Rhodospirillum rubrum. 1. Charakterisierung einer löslischen NADH-Dehydrogenase. Archiv für Mikrobiologie 62, 94-110.

BONNICHSEN, R. (1965). Ethanol determination with alcohol dehydrogenase and DPN. In Methods of Enzymatic Analysis, pp. 285-287. Edited by H. U. Bergmeyer. New York: Academic Press. 
Boulanger, P. \& Osteux, R. (1965). D-Amino acids. In Methods of Enzymatic Analysis, pp. 367-372. Edited by H. U. Bergmeyer. New York: Academic Press.

BüChER, T., CZOK, R., LAMPrecht, W. \& LATzKo, E. (1965). Pyruvate. In Methods of Enzymatic Analysis, pp. 253-259. Edited by H. U. Bergmeyer. New York: Academic Press.

Carlsson, J. (1972). Simplified gas chromatographic procedure for identification of bacterial metabolic products. Applied Microbiology 25, 287-289.

Carlsson, J., Frölander, F. \& Sundqvist, G. (1977). Oxygen tolerance of anaerobic bacteria isolated from necrotic dental pulps. Acta odontologica scandinavica 35, 139-145.

Coles, R. S. (1975). The effect of coenzyme leakage and replacement on the growth and metabolism of two fusobacteria. Journal of General Microbiology 86, 147-155.

COLES, R. S. (1977). Glucose utilization by resting cells of Fusobacterium polymorphum. Archives of Oral Biology 22, 87-90.

Czerkawski, J. W. \& Clapperton, J. L. (1968). Analysis of gases produced by metabolism of micro-organisms. Laboratory Practice 17, 994-997.

DoliN, M. I. (1953). The oxidation and peroxidation of $\mathrm{DPNH}_{2}$ in extracts of Streptococcus faecalis, 10c1. Archives of Biochemistry and Biophysics 46, 483-485.

DoliN, M. I. (1955). The DPNH-oxidizing enzymes of Streptococcus faecalis. II. The enzymes utilizing oxygen, cytochrome $c$, peroxide and 2,6-dichlorophenol-indophenol or ferricyanide as oxidants. Archives of Biochemistry and Biophysics 55, 415435.

Dolin, M. I. (1957). The Streptococcus faecalis oxidases for reduced diphosphopyridine nucleotide. III. Isolation and properties of a flavin peroxidase for reduced diphosphopyridine nucleotide. Journal of Biological Chemistry 225, 557-573.

Dolin, M. I. (1959). Oxidation of reduced diphosphopyridine nucleotide by Clostridium perfringens. 1. Relation of peroxide to the overall reaction. Journal of Bacteriology 77, 383-392.

DoliN, M. I. (1977). DPNH peroxidase: effector activities of $\mathrm{DPN}^{+}$. Biochemical and Biophysical Research Communications 78, 393-400.

Frölander, F. \& CARLsSON, J. (1977). Bactericidal effect of anaerobic broth exposed to atmospheric oxygen tested on Peptostreptococcus anaerobius. Journal of Clinical Microbiology 6, 117-123.

GaWeHN, K. \& Bergmeyer, H. U. (1970). D-(-)Lactat. In Methoden der Enzymatischen Analyse, 2nd edn, pp. 1450-1453. Edited by H. U. Bergmeyer. Weinheim, Germany: Verlag Chemie.

Gregory, E. M. \& Fridovich, I. (1974). Oxygen metabolism in Lactobacillus plantarum. Journal of Bacteriology 117, 166-169.

Griffith, C. J. \& Carlsson, J. (1974). Mechanism of ammonia assimilation in streptococci. Journal of General Microbiology 82, 253-260.

HoHorsT, H.-J. (1965). L-(+)-Lactate determination with lactic dehydrogenase and DPN. In Methods of Enzymatic Analysis, pp. 266-270. Edited by H. U. Bergmeyer. New York: Academic Press.
Holdeman, L. V. \& Moore, W. E. C. (1975). Anaerobe Laboratory Manual, 3rd edn. Blacksburg, Virginia: Virginia Polytechnic Institute and State University.

Hoshino, E., Yamada, T. \& Araya, S. (1976). Lactate degradation by a strain of Neisseria isolated from human dental plaque. Archives of Oral Biology 21, 677-683.

Hoskins, D. D., Whiteley, H. R. \& MACKLeR, B. (1962). The reduced diphosphopyridine nucleotide oxidase of Streptococcus faecalis: purification and properties. Journal of Biological Chemistry 237, 2647-2651.

KawaI, K., Yashima, S., OKami, Y. \& Sasaki, Y. (1971). Aerobic dissimilation of glucose by heterolactic bacteria. 1. Reduced pyridine nucleotide-oxidizing enzymes in Leuconostoc mesenteroides. Journal of General and Applied Microbiology 17, 51-62.

KING, T. E. \& Howard, R. L. (1967). Preparations and properties of soluble NADH dehydrogenases from cardiac muscle. Methods in Enzymology 10, 275-294.

LOESCHE, W. J. (1969). Oxygen sensitivity of various anaerobic bacteria. Applied Microbiology 18, 723-727.

Low, E. I. \& Zimkus, S. M. (1973). Reduced nicotinamide adenine dinucleotide oxidase activity and $\mathrm{H}_{2} \mathrm{O}_{2}$ formation of Mycoplasma pneumoniae. Journal of Bacteriology 116, 346-354.

Lowry, O. H., Rosebrough, N. J., Farr, A. L. \& RANDAll, R. J. (1951). Protein measurement with the Folin phenol reagent. Journal of Biological Chemistry 193, 265-275.

McCord, J. M. \& Fridovich, I. (1969). Superoxide dismutase, an enzymatic function for erythrocuprein (hemocuprein). Journal of Biological Chemistry 244, 6049-6055.

Minakami, S., Ringler, R. L. \& Singer, T. P. (1962). Studies on the respiratory chain-linked dihydrodiphosphopyridine nucleotide dehydrogenase. Journal of Biological Chemistry 237, 569-576.

Mizushima, S. \& Kitahara, K. (1962). Purification and properties of DPNH peroxidase in Lactobacillus casei. Journal of General and Applied Microbiology 8, 56-62.

MorRIs, J. G. (1975). The physiology of obligate anaerobiosis. Advances in Microbial Physiology 12, 169-246.

Morris, J. G. (1976). Oxygen and the obligate anaerobe. Journal of Applied Bacteriology 40, 229-244.

Möller, A. J. R. (1966). Microbiological examination of root canals and periapical tissues of human teeth. Göteborg: Akademiförlaget.

O'Brien, R. W. \& Morris, J. G. (1971). Oxygen and the growth and metabolism of Clostridium acetobutylicum. Journal of General Microbiology 68, 307-318.

Ottenstein, D. M. \& Bartley, D. A. (1971). Improved gas chromatography separation of free acids $\mathrm{C}_{2}-\mathrm{C}_{5}$ in dilute solution. Analytical Chemistry 43, 952-955.

Pritchard, G. G., Wimpenny, J. W. T., Morris, H. A., LewIS, M. W. A. \& Hughes, D. E. (1977). 
Effects of oxygen on Propionibacterium shermanii grown in continuous culture. Journal of General Microbiology 102, 223-233.

Robinson, J. \& COOPER, J. M. (1970). Method of determining oxygen concentrations in biological media, suitable for calibration of the oxygen electrode. Analytical Biochemistry 33, 390-399.

SeEgmiller, J. E. (1955). TPN-linked aldehyde dehydrogenase from yeast. Methods in Enzymology 1, 511-514.

SLEIN, M. W. (1965). D-Glucose determination with hexokinase and glucose-6-phosphate dehydrogenase. In Methods of Enzymatic Analysis, pp. 117-123. Edited by H. U. Bergmeyer. New York: Academic Press.

Tally, F. P., Stewart, R. P., Sutter, V. L. \&
Rosenblatt, J. E. (1975). Oxygen tolerance of fresh clinical anaerobic bacteria. Journal of Clinical Microbiology 1, 161-164.

dE VRies, W. \& Stouthamer, A. H. (1969). Factors determining the degree of anaerobiosis of Bifidobacterium strains. Archiv für Mikrobiologie 65, 275-287.

Walker, G. A. \& Kilgour, G. L. (1965). Pyridine nucleotide oxidizing enzymes of Lactobacillus casei. II. Oxidase and peroxidase. Archives of Biochemistry and Biophysics 111, 534-539.

YamadA, T. \& CARLsson, J. (1975). Regulation of lactate dehydrogenase and change of fermentation products in streptococci. Journal of Bacteriology 124, 55-61. 